\title{
Effect of essential oils of oregano (Origanum vulgare), thyme (Thymus vulgaris), orange (Citrus sinensis var. Valencia) in the vapor phase on the antimicrobial and sensory properties of a meat emulsion inoculated with Salmonella enterica
}

\author{
${ }^{1}$ Luna-Guevara J.J., ${ }^{1}$ Rivera-Hernández M., ${ }^{2}$ Arenas-Hernández M.M.P. and \\ 1,* Luna-Guevara M.L. \\ ${ }^{1}$ Department of Food Engineering, Faculty of Chemical Engineering, Benemerita Autonomous University of \\ Puebla, Mexico \\ ${ }^{2}$ Research Center in Microbiological Sciences, Postgraduate in Microbiology, Institute of Sciences, \\ Benemerita Autonomous University of Puebla. Street 18 south and San Claudio Avenue, Zip Code 72570, \\ Puebla, Mexico
}

\begin{abstract}
Article history:
Received: 6 September 2020

Received in revised form: 20

October 2020

Accepted: 20 November 2020

Available Online: 24 January 2021
\end{abstract}

Keywords:

Antimicrobial agents,

Sensory evaluation,

Salmonella,

Essential oils

DOI:

https://doi.org/10.26656/fr.2017.5(1).488

\begin{abstract}
The demand for healthier meat products is increasing remarkably and natural antimicrobial agents such as essential oils (EOs) are required, which can be applied in the vapor phase. For this experiment, the effectiveness of essential oils of oregano, thyme, and orange in the vapor phase on the microbiological and sensory characteristics of sausages inoculated with Salmonella enterica and stored at $4{ }^{\circ} \mathrm{C}$ during $72 \mathrm{hrs}$ and $144 \mathrm{hrs}$, were studied. Oregano EO with $2000 \mathrm{ppm}$ was the most effective treatment against Salmonella enterica with a logarithmic reduction of $1.97 \log _{10} \mathrm{CFU} / \mathrm{g}$ compared to thyme $1.36 \log _{10}$ $\mathrm{CFU} / \mathrm{g}$ and orange $1 \log _{10} \mathrm{CFU} / \mathrm{g}$ ) after $144 \mathrm{hrs}$. In relation to the general acceptance level, the meat product exposed to the orange EO in vapor phase presented the highest approval by the judges nevertheless, however, were the ones that showed the least reduction in the microbial population. Finally, the results showed that the addition of essential oil in the vapor phase to meat products exerted a bactericidal effect with higher EOs concentrations and some also caused alterations in the sensorial properties of the product.
\end{abstract}

\section{Introduction}

According to the US Center for Disease Control and Prevention (CDC), millions of diseases caused by pathogens present in food originate every year (Ahmed and Shimamoto, 2014). Salmonellosis is one of the most reported zoonotic diseases. It is estimated that $95 \%$ of these infections are associated with food of animal origin (Hernandez et al., 2005). Furthermore, some researchers have directly linked the consumption of contaminated meat with the appearance of outbreaks of salmonellosis (Torlak et al., 2012).

In Mexico, the Institute of Epidemiological Diagnosis and Reference and the General Directorate of Epidemiology of the Ministry of Health, analyzed 24,394 S. enterica isolate recovered from human and non-human samples, which were isolated between the years 1972 and 1999 (Gutiérrez et al., 2000). This work revealed that $4,926(20.2 \%)$ isolates were recovered from food, and of these, 2,217 (9.1\%) were obtained from meat and meat products. This information shows the potential risk of getting salmonellosis from consuming contaminated meat products.

The sausage occupies the first place in the intake in Mexico, according to the Mexican Meat Council (COMECARNE, 2018). Additionally, in recent years, it has been questioned the safety of using chemical additives, consumers increasingly demand the use of natural products as alternative preservatives in foods (Govaris et al., 2010). The application of new and potential natural antimicrobial agents has increased significantly from different sources, such as microbial metabolites, plant extracts, and spices for food application (Cueva et al., 2011).

The use of essential oils in the vapor phase to reduce foodborne pathogens and it has become a promising tool for food safety. The concentration of EOs necessary to inhibit/inactivate microorganisms can be minimized, and the antimicrobial effect can be ensured (Reyes et al., 2019). Based on these considerations, the objective of the study was the evaluation of the antimicrobial 
capacity of the essential oils in the vapor phase from oregano (Origanum vulgare), thyme (Thymus vulgaris) and orange (Citrus sinensis var. Valencia), on a sausage inoculated with Salmonella enterica.

\section{Materials and methods}

\subsection{Bacterial culture and inoculum preparation}

A Salmonella enterica strain was previously isolated from food and identified by selective media such as Brilliant Green Agar and Bismuth Sulfite Agar and IMViC biochemical tests. Molecular analyses as $16 \mathrm{~S}$ rRNA gene partial sequencing were used to confirm the identification of bacterial genera and species. Genomic DNA was obtained from culture sample (pellet of 500 $\mathrm{mL}$ ) of Salmonella sp. (problem strain), grown in $5 \mathrm{~mL}$ of LB broth at $37^{\circ} \mathrm{C}$ with agitation, to an optical density $600 \mathrm{~nm}$ (OD600) of 0.5. The standard method of alkaline lysis was used to perform total DNA purification (Sambrook et. al., 1989). Genomic DNA was used as a template for the $16 \mathrm{~S}$ rRNA partial gene amplification by PCR using primers CD16F (5'GGAGGCAGCAGTGGGGAATA-3') and CD16R (5'TGACGGGCGGTGTGTACAAG-3') and a reaction mixture with Buffer 10X, $20 \mathrm{mM}$ of $\mathrm{MgCl}_{2}, 10 \mu \mathrm{M}$ of dNTPs, $5 \mathrm{U} / \mu \mathrm{L}$ of Dream Taq DNA polymerase and $10 \mu \mathrm{M}$ of oligonucleotides to a final volume of $200 \mu \mathrm{L}$. The PCR conditions were $94^{\circ} \mathrm{C}$ for 5 mins followed by 30 cycles of $94^{\circ} \mathrm{C}$ for $45 \mathrm{seg}, 55^{\circ} \mathrm{C}$ for $50 \mathrm{seg}$ and $72^{\circ} \mathrm{C}$ for $1 \mathrm{~min}$ and a final extension cycle of $72^{\circ} \mathrm{C}$ for $5 \mathrm{~min}$.

The amplification product was $1062 \mathrm{bp}$ and PCR products were purified using kit QIAquick (Qiagen, Germany) according to the manufacturer. Sequencing of PCR product was performed in Biomolecular Detection Center, BUAP (Puebla, Mexico). The 16S rRNA partial gene sequence was compared to sequences deposited in the GenBank database of the National Center for Biotechnology Information (NCBI), using the BLAST (Basic Local Alignment Search Tool) algorithm.

The microorganism was stored at $-80^{\circ} \mathrm{C}$ grew with two consecutive transfers in tryptic soy broth (TSB; Difco, Becton Dickinson) and incubated at $37^{\circ} \mathrm{C}$ for 24 hrs. For the preparation of the bacterial inoculum, a population higher than $10^{7} \mathrm{CFU} / \mathrm{mL}$ was assured, with the adjustment to an optical density (OD) of 1.1 to 620 $\mathrm{nm}$. This was confirmed by counting in Trypticase Soy Agar medium (TSA; Bioxon, Mexico) plates incubated at $37^{\circ} \mathrm{C}$ for $24 \mathrm{hrs}$.

\subsection{Sample inoculation}

Meat sausages "Vienna" (Chimex ${ }^{\circledR}$ brand) were used, each piece had an average weight of $60 \mathrm{~g}$ and a length of $11 \mathrm{~cm}$. The sausages were inoculated by immersion according to the procedure reported by Luna et al. (2015) with some modifications, the samples were introduced in a sterile Ziploc ${ }^{\circledR}$ bag with $50 \mathrm{~mL}$ of TSB inoculated with a population of $10^{7} \mathrm{CFU} / \mathrm{mL}$ of $S$. enterica. Finally, the samples were constantly manual stirred for $1 \mathrm{~min}$ to ensure complete inoculation.

\subsection{Antimicrobial treatments}

\subsubsection{Vegetables materials and essential oils (EOs) obtention}

The oregano (Origanum vulgare), thyme (Thymus vulgaris), and oranges (Citrus sinensis var. Valencia) were purchased from a local market in Puebla, Mexico. The spices (oregano and thyme), were used in their dehydrated form (moisture content approximately $11 \%$ DB) and the orange fruits were selected according to their index of maturity (with an approximate value of 12.23, MI (Madurity Index): ${ }^{\circ}$ Brix/titratable acidity). The EOs were obtained according to the procedure reported by Masango (2005), using $200 \mathrm{~g}$ of thyme leaves, $250 \mathrm{~g}$ of oregano leaves, and $800 \mathrm{~g}$ of orange peels. They were subjected to distillation with a Clevenger type apparatus at different times: 110 mins, 75 mins, 138 mins with oregano, thyme, and orange, respectively.

\subsubsection{Efficacy of antimicrobials in vapor phase}

The antimicrobials agents were placed under a sterile glass plate with concentrations $(0,700,1000,1500$ and $2000 \mathrm{mg}$ of EO L $\mathrm{E}^{-1}$ ) and inoculated sausage pieces were introduced in a hermetically sealed plastic chamber (capacity of $1.8 \mathrm{~L}$ ) (Figure 1). Samples chilled at $4 \pm 1{ }^{\circ} \mathrm{C}$ were analyzed after 0,72 , and $144 \mathrm{hrs}$.

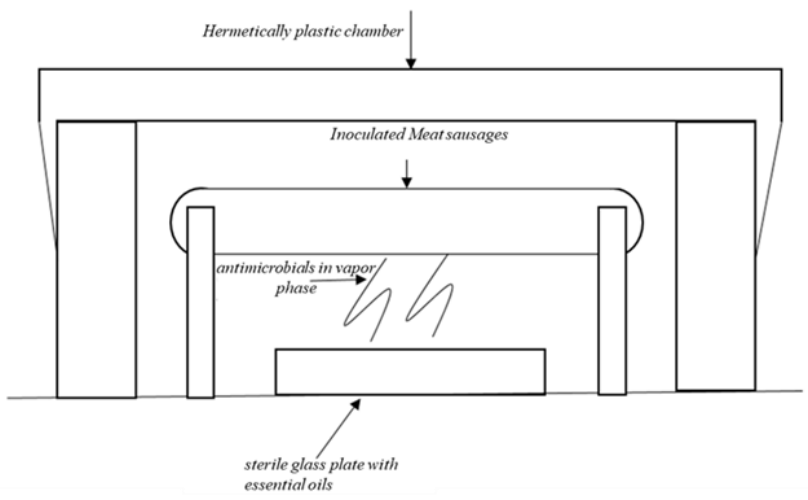

Figure 1. Design of the chamber for antimicrobial treatments with essential oils in vapor phase on emulsified products inoculated with Salmonella enterica

\subsubsection{Microbiological analysis}

After the storage times, the sausages (10 g) were removed aseptically from the chambers introduced in sterile stomacher (Mod 400 Interscience) bags with 90 
$\mathrm{mL}$ of peptone water $(0.1 \%)$ for homogenization for 1 min at high speed. The number of $S$. enterica cells were determined of serial dilutions which were spread on TSA plates and incubated at $35^{\circ} \mathrm{C}$ for $24 \mathrm{hrs}$. The identity of the colonies was confirmed with the classic IMViC biochemical tests and the kit proposed by Kim and Silva (2016), in which a change in color from green to orange confirmed a positive result. A parallel growth control was prepared to ensure that viable $S$. enterica cells and data were calculated as CFU because the entire sample was inoculated.

\subsection{Sensory evaluation}

Sensory analyzes were performed to know the level of acceptance and organoleptic alterations (color, aroma, taste and texture) of non-inoculated sausages exposed to the highest concentration (2000 of EO L $\left.{ }^{-1}\right)$ with each of the essential oils at $144 \mathrm{~h}$ of storage. The sessions were realized with a panel of 50 untrained judges, and the 5point hedonic scale was used $(5=$ I really like it, $4=\mathrm{I}$ like it, 3 = I like it $/ \mathrm{I}$ don't like it, 2 = I dislike it and $1=$ I dislike it a lot).

All determinations were made in triplicate, and the results of CFU/g were converted to $\log _{10}$ values for data analysis. Logarithmic reductions were calculated by the difference between $\log _{10} \mathrm{CFU} / \mathrm{g}$ control and $\log _{10} \mathrm{CFU} /$ $\mathrm{g}$ obtained of each treatment.

\subsection{Data analysis}

The results of the microbiological analyzes and the values of the sensory evaluations were analyzed by analysis of variance (ANOVA). The statistical program used was Minitab16 ${ }^{\circledR}$, considering $95 \%$ confidence, as a criterion of significant difference, between the samples. The significant differences between the average values were determined using the Tukey multiple comparison test.

\section{Results and discussion}

In this study, biochemical tests revealed that the Gram-negative bacteria isolated from food belonged to the genera Salmonella sp. Furthermore, the 16S rRNA partial gene sequence analysis of the strain confirmed for Salmonella enterica serovar Enteritidis. Figure 2 shows the behavior of $S$. enterica inoculated in chilled meats (common condition storage and marketing), this bacterium prevailed up to $144 \mathrm{hrs}$ in samples of the control, which coincides with that reported by Rocatto et al. (2015) who consider that temperature is a decisive extrinsic factor for the development of this microorganism. Further, Helmuth et al. (2019) consider that the microbial growth in sausages is due to the fact that the product has not received a heat treatment such as boil and frying it before consumption, or in some cases the product has been exposed to cross-contamination.
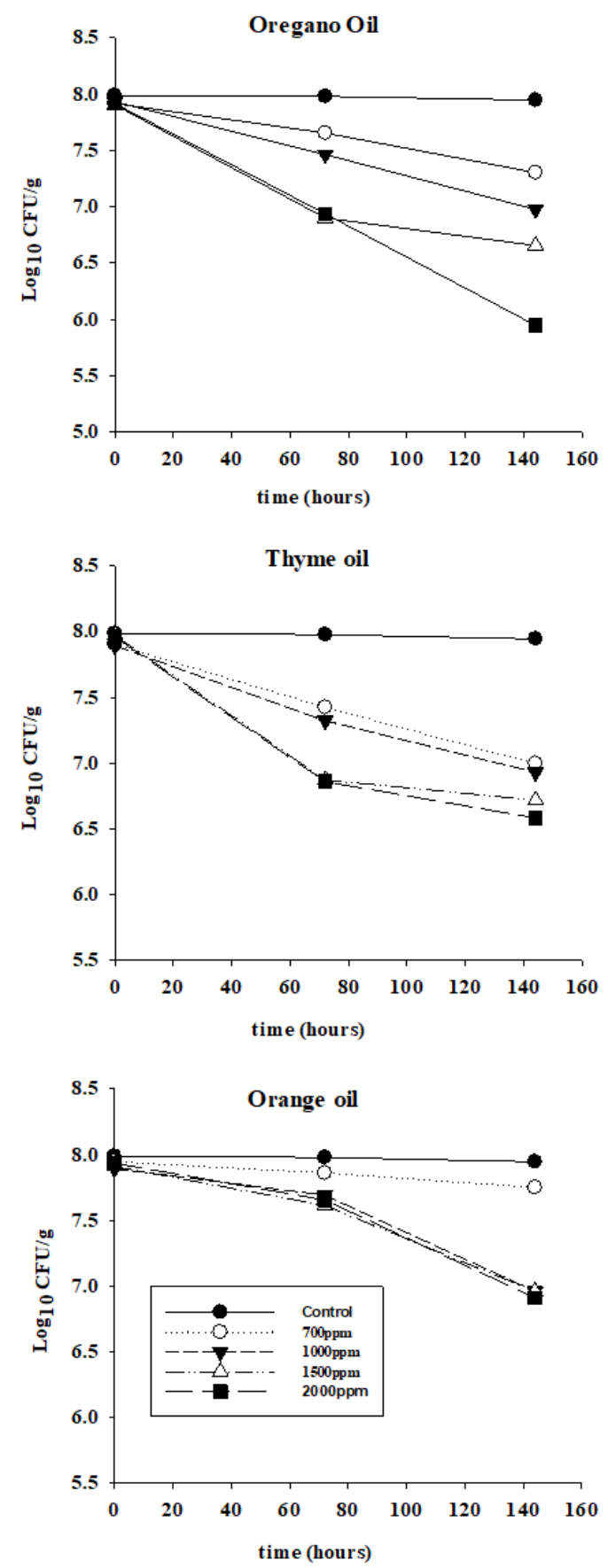

Figure 2. Salmonella enterica survival in emulsified meat product stored at $4^{\circ} \mathrm{C}$ for 72 and $144 \mathrm{hrs}$, exposed to the vapor phase of the essential oils of oregano, thyme and orange in concentrations of $0,700,1000,1500$ and $2000 \mathrm{mg}$ de EOs L ${ }^{-1}$ of air

The previous trend agrees with the study carried out by Nedorostova et al. (2009) who mention that essential oils can increase their antimicrobial properties if they are applied in the vapor phase, presenting an inhibitory effect on food pathogens including Salmonella enterica serovar Enteritidis. Likewise, the above is related to that established by Ukuku and Sapers (2007) who confirm that the cooling conditions $\left(4\right.$ to $\left.5^{\circ} \mathrm{C}\right)$ reduce the 
volatilization rate of the EOs, favoring that the aromatic compounds come into contact with the entire surface of the inoculated product. Additionally, Gram-negative bacteria such as Salmonella are more susceptible to the effects of essential oils due to the hydrophobicity of their membrane, causing protons such as potassium ions to escape and inhibition in ATP synthesis (Fisher et al., 2009; Tyagi and Malik, 2011).

According to a study by Matan et al. (2006), the antimicrobial effectiveness of EOs in the vapor phase depends on the composition of the atmosphere. While Mazzarrino et al. (2015), mention that oregano and thyme are more effective antimicrobial agents on microorganisms of importance in food such as Salmonella and Listeria compared to the effect of EOs from orange. In a particular way López et al. (2007), report that carvacrol present in oregano EO in the vapor phase, and exposure for $6 \mathrm{hrs}$ inhibited $70 \%$ of the Salmonella population. Another report indicates that $\mathrm{p}$ cymene, also contained in thyme, has activity on pathogens and spoilage microbiota present in meat $(\mathrm{Lu}$ and $\mathrm{Wu}, 2010)$.

The OE of oregano and thyme did not show a significant difference at concentration $1500 \mathrm{ppm}$ with a storage time of $144 \mathrm{hrs}$, with logarithmic reductions 1.25 $\log _{10} \mathrm{CFU} / \mathrm{g}$ and $1.22 \log _{10} \mathrm{CFU} / \mathrm{g}$, respectively. According to Oyedemi et al. (2009), the mechanisms of the action exerted by oregano oils are related to cell lysis by altering the lipid disposition of the membrane, with effects on its permeability.

Some studies, such as $\mathrm{Lu}$ and $\mathrm{Wu}$ (2010) demonstrated the inhibitory antimicrobial activity of thyme essential oil (200 ppm) achieved 4 Log reductions of Salmonella. While Nedorostova et al. (2009) confirmed the effectiveness of this spice on S. enterica ser. Enteritidis and $S$. enterica ser. Choleraesuis, the latter reported a $60 \%$ reduction in population when applying vapor phase treatments. In the investigation of Sartoratto et al. (2004) associated the antimicrobial effects of thyme with the contents of thymol, $\alpha$ terpinene, and $p$-cymene.

Orange peel EO had the highest Log reductions with the higher concentrations (1500 and $2000 \mathrm{mg}$ of EO L $\mathrm{E}^{-1}$ ) and $144 \mathrm{~h}$ of contact (Figure 2 and Table 1). These results correspond to those reported by the Tosun et al. (2018), who found inhibition of Salmonella until $96 \mathrm{hrs}$ in inoculated salmon. According to Velázquez et al. (2013), the main compounds of the orange peel EO correspond to limonene, $\beta$-myrcene, $\beta$-pinene, $\alpha$-pinene, as well as limonene representing $96.62 \%$. Besides, Tyagi and Malik (2011) reported that monoterpenes concentrations in EOs are the main components with higher antimicrobial activity in the vapor phase than in direct contact and depend on their presence in gaseous form facilitating their solubilization in cell membranes. At the same time as Bajpai et al. (2012) confirmed that the limonene affects the cell membrane integrity inhibiting 90\% Salmonella growth.

Table 1 shows the effect of EOs treatments in the vapor phase and contact times on the Log reductions of $S$. enterica. The most effective treatment on the Salmonella enterica population (1.97 $\log _{10} \mathrm{CFU} / \mathrm{g}$ ) was EOs of oregano with $2000 \mathrm{mg}$ of EO L ${ }^{-1}$ compared to thyme (1.36 $\left.\log _{10} \mathrm{CFU} / \mathrm{g}\right)$ and orange $\left(1 \log _{10} \mathrm{CFU} / \mathrm{g}\right)$.

Table 1. Logarithmic reductions of Salmonella enterica in emulsified meat product exposed to essential oils in the vapor phase stored at $4^{\circ} \mathrm{C}$

\begin{tabular}{cccc}
\hline & Treatment & \multicolumn{2}{c}{ Storage time (hrs) } \\
\hline Essential oil & $\begin{array}{c}\text { Concentration } \\
\text { (mg of EO L } \text { of air }^{-1}\end{array}$ & 72 & 144 \\
\hline \multirow{3}{*}{ Oregano } & 700 & $0.26 \mathrm{~g} \mathrm{~K}$ & $0.61 \mathrm{e} \mathrm{H}$ \\
& 1000 & $0.47 \mathrm{f} \mathrm{J}$ & $0.96 \mathrm{~d} \mathrm{FG}$ \\
& 1500 & $1.01 \mathrm{c} \mathrm{E}$ & $1.25 \mathrm{~b} \mathrm{C}$ \\
Thyme & 2000 & $0.98 \mathrm{~cd} \mathrm{EF}$ & $1.97 \mathrm{a} \mathrm{A}$ \\
\hline \multirow{3}{*}{ Orange } & 100 & $0.55 \mathrm{~g} \mathrm{I}$ & $0.94 \mathrm{e} \mathrm{FG}$ \\
& 1500 & $0.65 \mathrm{f} \mathrm{H}$ & $1.01 \mathrm{~d} \mathrm{E}$ \\
& 2000 & $1.10 \mathrm{c} \mathrm{D}$ & $1.22 \mathrm{~b} \mathrm{C}$ \\
& 700 & $1.12 \mathrm{c} \mathrm{D}$ & $1.36 \mathrm{a} \mathrm{B}$ \\
\hline & 1000 & $0.08 \mathrm{e} \mathrm{M}$ & $0.19 \mathrm{~d} \mathrm{~L}$ \\
& 1500 & $0.29 \mathrm{c} \mathrm{K}$ & $0.95 \mathrm{~b} \mathrm{FG}$ \\
& 2000 & $0.28 \mathrm{c} \mathrm{K}$ & $1.01 \mathrm{a} \mathrm{E}$ \\
\hline
\end{tabular}

Logarithmic reductions represent the relationship between the average of $\log \mathrm{CFU} / \mathrm{g}$ of control $\left(\log _{10} 7 \mathrm{CFU} / \mathrm{g}\right)$ and the $\log _{10} \mathrm{CFU} / \mathrm{g}$ of the emulsified meat product exposed to each treatment. Different lowercase letters indicate significant differences $(p<0.05)$ for the same essential oil treatment. Different capital letters indicate significant difference $(p<0.05)$ among all treatments.

\subsection{Effect of essential oils in the vapor phase in sensorial properties in sausages}

The sensory attributes were evaluated at concentrations of $2000 \mathrm{mg}$ of EOs L $\mathrm{L}^{-1}$ of essential oil of oregano (Origanum vulgare), thyme (Thymus vulgaris), and orange peel (Citrus sinensis var. Valencia) by 144 hrs. The results of the sensorial analysis are presented in Table 2. The results were the average of scores which the examiners gave to each sample. Based on a 5-point hedonic scale, values more than three were considered organoleptically acceptable. As can be seen, when the attributes of aroma, texture, color, and flavor were evaluated, they did not present a significant difference $(\mathrm{P} \geq 0.05)$. However, the attribute with the lowest values was the flavor of sausages treated with EOs of oregano 
Table 2. Sensory evaluation of sausage in contact with the vapor phase of different essential oils

\begin{tabular}{lccc}
\hline \multicolumn{1}{c}{ Attribute } & Orange (Citrus sinensis var. Valencia) & Oregano (Origanum vulgare) & Thyme (Thymus vulgaris) \\
\hline Odor & $3.70 \pm 1.13^{\mathrm{a}}$ & $3.40 \pm 1.15^{\mathrm{a}}$ & $3.67 \pm 0.82^{\mathrm{a}}$ \\
Texture & $3.80 \pm 0.07^{\mathrm{a}}$ & $3.75 \pm 0.83^{\mathrm{a}}$ & $3.55 \pm 0.90^{\mathrm{a}}$ \\
Color & $3.91 \pm 1.15^{\mathrm{a}}$ & $4.22 \pm 0.69^{\mathrm{a}}$ & $4.15 \pm 0.53^{\mathrm{a}}$ \\
Taste & $3.17 \pm 1.03^{\mathrm{a}}$ & $2.87 \pm 1.20^{\mathrm{a}}$ & $2.62 \pm 1.25^{\mathrm{a}}$ \\
General acceptance & $3.65 \pm 0.80^{\mathrm{a}}$ & $3.25 \pm 1.05^{\mathrm{ab}}$ & $2.97 \pm 1.18^{\mathrm{b}}$ \\
Final Score & $3.61^{\mathrm{a}}$ & $3.49^{\mathrm{b}}$ & $3.39^{\mathrm{c}}$ \\
\hline
\end{tabular}

Different letters in the columns indicate significant difference $(\mathrm{p} \leq 0.05)$

and thyme respectively. The application of larger amounts of essential oils could seriously interfere with the final organoleptic properties (Lis-Balchin et al., 1998). In this study, a bactericidal effect was obtained at higher oil concentrations, although in this case, there were changes in taste parameters. According to Busatta et al. (2008), reducing the concentration of EOs would help to achieve a well-balanced product, satisfying the antimicrobial and acceptability aspects of consumer requirements. Finally, concerning the general acceptance, the EO in the orange vapor phase was the one that presented the highest approval by the judges. However, these meat products were the ones that showed the least reduction in the microbial population.

\section{Conclusion}

With the results shown in our study, it can be concluded that the EOs applied in the vapor phase significantly reduced the Salmonella population in sausages stored until $144 \mathrm{hrs}$ under refrigerated conditions. Specifically, the highest reductions were presented with 1500 and $2000 \mathrm{mg}^{\circ} \mathrm{EO} \mathrm{L}^{-1}$ with the EO of oregano, while the results of the sensory analyzes with sausages exposed to the EO of orange (2000 mg of EO L ${ }^{-1}$ ) indicated the highest values in the attributes of color, flavor and general acceptance. Finally, considering the EOs applied in the vapor phase results in a viable alternative to be used in the meat industry, it also represents an option to process waste such as orange peel to obtain natural antimicrobial agents with use-value in food.

\section{Conflict of interest}

The authors declare no conflict of interest.

\section{Acknowledgments}

The authors thank to Vicerrectoría de Investigación y Estudios de Posgrado of Benemérita Universidad Autónoma de Puebla by its support for the realization of the present investigation and MC Mayra Juarez Almaraz by her participation in the translation and review of this paper.

\section{References}

Ahmed, A.M. and Shimamoto, T. (2014). Isolation and molecular characterization of Salmonella enterica, Escherichia coli O157: H7 and Shigella spp. from meat and dairy products in Egypt. International Journal of Food Microbiology, 168-169, 57-62. https://doi.org/10.1016/j.ijfoodmicro.2013.10.014

Bajpai, V.K., Baek, K.H. and Kang, S.C. (2012). Control of Salmonella in foods by using essential oils: A review. International Food Research Journal, 45(2), 722-734.

https://doi.org/10.1016/ j.foodres.2011.04.052

Busatta, C., Vidal, R.S., Popiolski, A.S., Mossi, A.J., Dariva, C., Rodrígues, M.R.A., Corazza, F.C., Corazza, M.L., Vladimir Oliveira, J. and Cansian, R. L. (2008). Application of Origanum majorana L. essential oil as an antimicrobial agent in sausage. Food Microbiology, 25(1), 207-211. https:// doi.org/10.1016/j.fm.2007.07.003

COMECARNE. (2018). Mexican Meat Council. Retrieved on July 11, 2019 from Comecarne website: https://comecarne.org/wp-content/ uploads/2019/04/Compendio-Estadi\%CC\%81stico2018-VF.pdf.

Cueva, C., Moreno-Arribas, M.V., Bartolomé, B., Salazar, Ó., Vicente, M.F. and Bills, G.F. (2011). Antibiosis of vineyard ecosystem fungi against foodborne microorganisms. Microbiological Research, 162(10), 1043-1051. https://doi.org/10.1016/ j.resmic.2011.09.002

Fisher, K., Phillips, C. and Mcwatt, L. (2009). The use of an antimicrobial citrus vapor to reduce Enterococcus sp. on salad products. International Journal of Food Science and Technology, 44(9), 1748-1754. https:// doi.org/10.1111/j.1365-2621.2009.01992.x

Govaris, A., Solomakos, N., Pexara, A. and Chatzopoulou, P. (2010). The antimicrobial effect of oregano essential oil, nisin and their combination against Salmonella Enteritidis in minced sheep meat during refrigerated storage. International Journal of Food Microbiology, 137(2-3), 175-180. https:// doi.org/10.1016/j.ijfoodmicro.2009.12.017 
Gutiérrez, L., Montiel, E., Aguilera, P. and González, M. (2000). Serotipos de Salmonella identificados en los servicios de salud de México. Salud Pública de México, 42, 490-495. [In Spanish]. https:// doi.org/10.1590/S0036-36342000000600004

Helmuth, I.G., Espenhain, L., Ethelberg, S., Jensen, T., Kjeldgaard, J., Litrup, E., Schjørring S. and Müller, L. (2019). An outbreak of monophasic Salmonella Typhimurium associated with raw pork sausage and other pork products, Denmark 2018-19. Epidemiology and Infection, 147, 1-7. https:// doi.org/10.1017/S0950268819002073

Hernandez, T., Sierra, A., Rodriguez-Alvarez, C., Torres, A., Arevalo, M.P., Calvo, M. and Arias, A. (2005). Salmonella enterica serotypes isolated from imported frozen chicken meat in the Canary Islands. Journal of Food Protection, 68(12), 2702-2706. https://doi.org/10.4315/0362-028X-68.12.2702

Kim, T.J. and Silva, J.L. (2016). Salmonella and Listeria assay methods and kits. U.S. Patent Application No. 14/871,836.

Lis-Balchin, M., Buchbauer, G., Hirtenlehner, T. and Resch, M. (1998). Antimicrobial activity of Pelargonium essential oils added to a quiche-filling as a model food system. Letters in Applied Microbiology, 27(4), 207-210. https:// doi.org/10.1046/j.1472-765X.1998.t01-1-00423.x

López, P., Sanchez, C., Batlle, R. and Nerin, C. (2007). Vapor-Phase Activities of Cinnamon, Thyme, and Oregano Essential Oils and Key Constituents against Foodborne Microorganism. Journal of Agricultural and Food Chemistry, 55, 4348-4355. https:// doi.org/10.1021/jf063295u

Lu, Y. and Wu, C. (2010). Reduction of Salmonella enterica contamination on grape tomatoes by washing with thyme oil, thymol, and carvacrol as compared with chlorine treatment. Journal of Food Protection, 73(1), 2270-2275. https:// doi.org/10.4315/0362-028X-73.12.2270

Luna, M.G., Luna, J.G., Ruiz, H.E., Leyva, L.A. and Díaz, C.G. (2015). Efficacy of disinfection treatments using essential oils and ultrasound on tomato fruits inoculated with Escherichia coli and impact on antioxidant activity. Revista Argentina de Microbiología, 47(3), 251-255. https:// doi.org/10.1016/j.ram.2015.04.004

Masango, P. (2005). Cleaner production of essential oils by steam distillation. Journal of Cleaner Production, 13(8), 833-839. https://doi.org/10.1016/ j.jclepro.2004.02.039

Matan, N., Rimkeeree, H., Mawson, A.J., Chompreeda, P., Haruthaithanasan, V. and Parker, M. (2006).
Antimicrobial activity of cinnamon and clove oils under modified atmosphere conditions. International Journal of Food Microbiology, 107(2), 180-185. https://doi.org/10.1016/j.ijfoodmicro.2005.07.007

Mazzarrino, G., Paparella, A., Chaves-López, C., Faberi, A., Sergi, M., Sigismondi, C., Compagnone D. and Serio, A. (2015). Salmonella enterica and Listeria monocytogenes inactivation dynamics after treatment with selected essential oils. Food Control, 50, 794803. https://doi.org/10.1016/j.foodcont.2014.10.029

Nedorostova, L., Kloucek, O., Hokoska, L., Stolcova, M. and Pulkrabek, J. (2009). Antimicrobial properties of selected essential oils in vapour phase against foodborne bacteria. Food Control, 20(2), 157-160. https://doi.org/10.1016/j.foodcont.2008.03.007

Oyedemi, S.O., Okoh, A.I., Mabinya, L.V., Pirochenva, G. and Afolayan, A.J. (2009). The proposed mechanism of bactericidal action of eugenol, $\square$ terpineol and g-terpinene against Listeria monocytogenes, Streptococcus pyogenes, Proteus vulgaris and Escherichia coli. African Journal of Biotechnology, 7, 1280-1286.

Reyes, F., Navarro, A.R., Ochoa, C.E., Palou, E., LópezMalo, A. and Ávila-Sosa, R. (2019). Essential oils in vapor phase as alternative antimicrobials: A review. Critical Reviews in Food Science and Nutrition, 60 (10), $\quad 1641 \quad-\quad 1650 . \quad$ https:// doi.org/10.1080/10408398.2019.1586641.

Roccato, A., Uyttendaele, M., Cibin, V., Barrucci, F., Cappa, V., Zavagnin, P., Targa Longo A.R., Catellani P. and Ricci, A. (2015). Effects of domestic storage and thawing practices on Salmonella in poultry-based meat preparations. Journal of Food Protection, 78(12), 2117-2125. https://doi.org/10.4315/0362-028X.JFP-15-048

Sartoratto, A., Machado, A.L.M., Delarmelina, C., Figueira, G.M., Duarte, M.C.T. and Rehder, V.L.G. (2004). Composition and antimicrobial activity of essential oils from aromatic plants used in Brazil. Brazilian Journal of Microbiology, 35, 275-280. https://doi.org/10.1590/S1517-83822004000300001

Sambrook, J., Fritsch, E.F. and Maniatis, T. (1989). Molecular Cloning, A laboratory manual. Cold Spring Harbor, New York: Cold Spring Harbor Laboratory Press.

Torlak, E., Akan, İ.M. and İnal, M. (2012). Evaluation of Rapid Check Select for the screening of Salmonella in meat and meat products. Journal of Microbiological Methods, 90(3), 217-219. https:// doi.org/10.1016/j.mimet.2012.05.010

Tosun, Ş.Y., Üçok Alakavuk, D., Ulusoy, Ş. and Erkan, N. (2018). Effects of essential oils on the survival of 
Salmonella enteritidis and Listeria monocytogenes on fresh Atlantic salmons (Salmo salar) during storage at $2 \pm 1{ }^{\circ} \mathrm{C}$. Journal of Food Safety, 38(1), 12408. https://doi.org/10.1111/jfs. 12408

Tyagi, A.K. and Malik, A. (2011). Antimicrobial potential and chemical composition of Eucalyptus globulus oil in liquid and vapor phase against food spoilage microorganisms. Food Chemistry, 126(1), 228-235.

https://doi.org/10.1016/ j.foodchem.2010.11.002

Ukuku, D.O. and Sapers, G.M. (2007). Effect of time before storage and storage temperature on survival of Salmonella inoculated on fresh-cut melons. International Journal of Food Microbiology, 24(3), 288-295. https://doi.org/10.1016/j.fm.2006.04.007

Velázquez-Nuñez, M.J., Avila-Sosa, R., Palou, E. and López-Malo, A. (2013). Antifungal activity of orange (Citrus sinensis var. Valencia) peel essential oil applied by direct addition or vapor contact. Food Control, 31(1), 1-4. https://doi.org/10.1016/ j.foodcont.2012.09.029 